Bartlett, G. W. \& Moses, V. (1957). J. gen. Microbiol. 16, 550-560

\title{
The Pathway of Glucose Metabolism in Zygorrhynchus moelleri
}

\author{
By G. W. BARTLETT* AND V. MOSES $\dagger$ \\ Botany Department, University College, London
}

SUMMARY : Radioactive glucose has been supplied to starved and unstarved cells of the fungus Zygorrhynchus moelleri for short periods of time, and a partial analysis was made of the nature of those substances incorporating radiocarbon from labelled glucose. It was found that although glucose was metabolized more rapidly by unstarved cells it rapidly entered the cells in both nutritional states and was converted to a number of other substances within the first 15 sec. Differences were found in the pattern of incorporation of labelled carbon between starved and unstarved cells, suggesting that starvation resulted in a disturbance of the balance of the relative metabolic pathways utilized for glucose metabolism in unstarved cells.

In further experiments cells were prepared in four physiological states: growing, resting after growth, starved in buffer, and after metabolizing glucose for several hours subsequent to starvation. By use of substrates variously labelled with radiocarbon it was found that the extent of recycling in the tricarboxylic acid cycle, which is similar in growing and resting cells, rose considerably when the cells were starved, and remained high for several hours during the incubation of starved cells with glucose. The minimum percentage of glucose which was metabolized primarily at the $\mathrm{C}_{1}$ position rose from $11 \%$ in growing cells to $19 \%$ in resting cells, fell nearly to zero immediately following starvation, and increased to $5 \%$ after some hours in the presence of glucose.

Cells of the fungus Zygorrhynchus moelleri, when starved for $\mathbf{2 4} \mathrm{hr}$. in phosphate buffer and then supplied with glucose, show a lag period of 2-3 hr. before the rates of respiration and glucose utilization become constant at their maximum values (Moses, 1954, 1955a). There is no appreciable lag with unstarved cells. Some evidence has been adduced (Moses, 1955b) suggesting that this lag may be due to some extent to a partial metabolic blockage on the pathway of glucose metabolism. A further investigation of the mechanism of glucose metabolism in this fungus is made in the present work by the use of two different types of technique.

In the first case starved and unstarved cells were allowed to metabolize uniformly labelled glucose for short periods of time. Attempts were then made to determine the nature of those compounds incorporating ${ }^{14} \mathrm{C}$ from labelled glucose and to investigate differences in glucose metabolism exhibited by cells in the two different physiological conditions.

In the second series of experiments cells from four physiological states were used: growing cells, resting unstarved cells, starved cells, and starved cells which had been allowed to metabolize glucose for $3 \mathrm{hr}$. Experiments were carried out to assess the relative extents in the cells of recycling within the

\footnotetext{
* Present address: Physical Chemistry Laboratory, South Parks Road, Oxford.

$\dagger$ Present address: Radiation Laboratory, University of California, Berkeley 4, California,
} U.S.A. 
tricarboxylic acid cycle and of the percentage of glucose metabolized via an asymmetrical oxidative route rather than by a symmetrical pathway such as the Embden-Meyerhof glycolysis scheme.

\section{METHODS}

Incorporation of radioactivity from $\left({ }^{14} \mathrm{C}\right)$ glucose. Fungal hyphae were grown and, when required, starved for $24 \mathrm{hr}$. in $0 \cdot 067 \mathrm{M}$-phosphate buffer, $\mathrm{pH} 6 \cdot 8$, as described by Moses (1954). The cells, starved or unstarved, were suspended in distilled water at a concentration of $12 \mathrm{mg}$. dry wt./ml., dispensed into a number of flasks in $5 \mathrm{ml}$. quantities and shaken at $25^{\circ}$. To each flask was added $1 \mathrm{ml}$. of a solution of uniformly labelled glucose (12.5 $\mu \mathrm{c}$; $160 \mu \mathrm{g}$.). After incubation in the presence of $\left({ }^{14} \mathrm{C}\right)$ glucose for $15 \mathrm{sec}$., $45 \mathrm{sec}$., $2 \mathrm{~min}$., 6 min., and, in the case of starved cells, $20 \mathrm{~min}$., the cells were killed by the addition of $20 \mathrm{ml}$. of boiling ethanol and were subsequently extracted at $80^{\circ}$ for a further $30 \mathrm{~min}$. The cell debris was removed by centrifugation and the ethanol extract evaporated to dryness in vacuo at room temperature.

The residue was dissolved in water and separated into three fractions by ion-exchange chromatography using the resins Amberlite IR-120 (in the $\mathbf{H}$ form) and Amberlite IR-4B (in the OH form) (Claridge \& Werkman, 1954). The 'cationic' fraction, retained by and subsequently eluted from IR-120, contained inorganic cations and amino acids; the 'anionic' fraction contained inorganic anions and organic acids retained by and subsequently eluted from IR-4B; malate and citrate were not absorbed by this resin, and appeared with uncharged substances in the 'non-ionic' fraction. Each fraction was assayed for radio-activity by methods previously described (Moses, 1957) and was also subjected to two-dimensional paper chromatography using $80 \%(\mathrm{v} / \mathrm{v})$ phenol in water in the presence of $\mathbf{N H}_{3}$ as the solvent for the first dimension, and butyric acid:butanol:water $(2: 1: 1)$ for the second dimension (Aronoff \& Vernon, 1950). Radioactive substances were located on the chromatograms by radioautography.

The identity of some of the radioactive substances present in the cell extracts was determined, whilst the nature of others remains unknown. Glutamic, succinic, malic, and citric acids, glucose, glucose-1-phosphate, and fructose-1:6-diphosphate were first tentatively identified from their positions on the chromatograms. The spots of these substances were cut out, eluted with water, and co-chromatographed with authentic samples of the suspected compounds. All substances were chromatographed in the two-dimensional solvent system used above, and use was also made of the solvent systems mentioned below. Identity of the radioactive area with the exact shape and position of the known marker after spraying, in several solvent systems, was taken as the criterion of identification of a substance.

The solvent systems used for the investigation of the active substances were as follows : organic acids were run in tert-amyl alcohol: chloroform: water : $98 \%$ $(\mathrm{v} / \mathrm{v})$ formic acid $(8: 8: 8: 3 ;$ L. E. Bentley, personal communication), and located by spraying the dried chromatograms with mixed methyl-yellow-bromophenol 
blue indicator (Claridge \& Werkman, 1954). Amino acids were chromatographed in $80 \%(\mathrm{v} / \mathrm{v})$ aqueous phenol in an atmosphere of $\mathrm{NH}_{3}$ and located with ninhydrin. Sugars and other reducing substances were run in a mixture of methanol:ethanol:water (2:2:1; Norris \& Campbell, 1949), and were detected by an ammoniacal $\mathrm{AgNO}_{3}$ spray (Trevelyan, Procter \& Harrison, 1950). Phosphate esters were chromatographed on washed filter-paper in a solvent containing $90 \%(\mathrm{v} / \mathrm{v})$ formic acid:isopropyl ether $(2: 3$; Hanes \& Isherwood, 1949). The esters were detected by the technique of Bandurski \& Axelrod (1951), modified from that of Hanes \& Isherwood (1949).

Incorporation of radioactivity from carboxyl-labelled acetate. Hyphae were grown for $18 \mathrm{hr}$. in $150 \mathrm{ml}$. of medium. The cells were harvested, washed and resuspended in $150 \mathrm{ml}$. of $0.067 \mathrm{M}$-phosphate buffer, $\mathrm{pH} \mathrm{6 \cdot 8}$. The cell suspension was divided into three equal parts.

Sample I was supplied with $0.02 \mathrm{M}$-glucose and shaken for $3 \mathrm{hr}$. at $25^{\circ}$. The cells were then centrifuged and resuspended in $50 \mathrm{ml}$. of $0.067 \mathrm{M}$-phosphate buffer ( $\mathrm{pH} \mathrm{6.8}$ ) containing $0.02 \mathrm{M}$-glucose and $0.002 \mathrm{M}-\mathrm{Na}$ acetate in a $500 \mathrm{ml}$. Erlenmeyer flask. Carboxyl-labelled acetate (0.44 mg.; $28 \mu \mathrm{c}$.) was added and a small sample of the suspension taken for assay of the initial radioactivity in the medium; the cells were shaken for $1 \mathrm{hr}$. at $25^{\circ}$, then centrifuged and resuspended in ethanol. Simultaneously with the above experimental arrangement monitor Warburg flasks were set up containing $2 \mathrm{ml}$. of cell suspension and corresponding quantities of labelled and unlabelled substrates, together with $0.2 \mathrm{ml}$. of $\mathrm{N}-\mathrm{KOH}$ in order to trap respiratory $\mathrm{CO}_{2}$. Samples of the medium and $\mathrm{KOH}$ were removed at the end of the experiment for radioactivity determinations. The gas phase was air.

Cells of sample II were starved by being shaken in buffer for $24 \mathrm{hr}$. They were then centrifuged and resuspended in buffer; substrates were added and Warburg flask monitors set up exactly as in the case of sample I. The cells were shaken for $1 \mathrm{hr}$. after the addition of substrates; they were then treated with ethanol and samples taken as before.

Cells of sample III were starved in buffer for $\mathbf{2 4} \mathrm{hr}$., and then supplied with $0.02 \mathrm{M}$-glucose for $3 \mathrm{hr}$. The cells were finally centrifuged, resuspended in buffer and substrates were added as described for the other two samples. These cells were also shaken for $1 \mathrm{hr}$. before samples of the medium and $\mathbf{K O H}$ were removed and the cells suspended in ethanol.

The ethanolic suspension of each batch of cells was evaporated to dryness. The residue was hydrolysed and glutamic acid isolated from each batch of hydrolysate. The specific radioactivity of each glutamic acid sample was determined; each sample of glutamic acid was also decarboxylated with Clostridium welchii S.R. 12, and the specific activity of the $\alpha$-carboxyl carbons measured. The techniques employed have been described elsewhere (Moses, 1957).

Respiration of labelled glucose. The production of respiratory ${ }^{14} \mathrm{CO}_{2}$ from

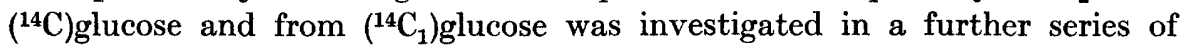
experiments. Three samples of cells in different physiological states were prepared, corresponding to samples I, II and III in the previous section. 
A further sample (IV) was prepared corresponding to the growing cells used in an earlier investigation (Moses, 1957). The latter were grown for $13 \mathrm{hr}$. only instead of the customary $18 \mathrm{hr}$., and were subsequently resuspended in a modified growth medium containing glucose and acetate as carbon source, and shaken in an atmosphere of pure $\mathrm{O}_{2}$ (Moses, 1957).

Cells of sample I were allowed to metabolize $0.02 \mathrm{M}$-glucose for $3 \mathrm{hr}$. after growth as in the first experiment. After resuspension in $50 \mathrm{ml}$. of $0.067 \mathrm{M}$ phosphate buffer, $\mathrm{pH} 6 \cdot 8$, the cells were dispensed into Warburg flasks in $2 \mathrm{ml}$. quantities. Glucose labelled with ${ }^{14} \mathrm{C}$ either uniformly or in the $\mathrm{C}_{1}$ position $(2 \mu \mathrm{c}$.) was added to each flask to give a final concentration of $0.002 \mathrm{M}$. $\mathrm{KOH}$ was added to the centre wells to trap the ${ }^{14} \mathrm{CO}_{2}$ evolved, and the cells were shaken for $1 \mathrm{hr}$. at $25^{\circ}$. A similar experiment was conducted in which the cells, having metabolized glucose for $3 \mathrm{hr}$. after growth, were placed in an atmosphere of pure $\mathrm{N}_{2}$ and allowed to ferment the two species of labelled glucose supplied. The ${ }^{14} \mathrm{CO}_{2}$ evolved was again trapped in $\mathrm{KOH}$.

The starved cells of sample II were supplied with labelled glucose immediately after being shaken in buffer for $24 \mathrm{hr}$. The respiratory ${ }^{14} \mathrm{CO}_{2}$ was collected for $1 \mathrm{hr}$. at $\mathbf{2 5}^{\circ}$.

With sample III, labelled glucose was supplied to the starved cells for $\mathbf{l} \mathrm{hr}$. following a preliminary $3 \mathrm{hr}$. period for the metabolism of unlabelled glucose $(0.02 \mathrm{M})$. In all these instances the gas phase was air.

The cells from the modified growth medium (sample IV) were incubated for $1 \mathrm{hr}$. at $25^{\circ}$ in an atmosphere of $\mathrm{O}_{2}$. The labelled glucoses were then added, and the cells shaken for $1 \mathrm{hr}$. longer in $\mathrm{O}_{2}$.

In each case samples of the medium (after removal of the cells) and of the $\mathrm{KOH}$ were taken at the end of the incubation period for radioactivity determinations on the residual glucose, and on the respiratory ${ }^{14} \mathrm{CO}_{2}$ evolved, respectively. There was no significant source of radioactivity in the medium after the experiment other than glucose.

The various specimens were assayed for radioactivity by the same techniques as were used in earlier work (Moses, 1957).

Substances containing ${ }^{14} \mathrm{C}$ were obtained from The Radiochemical Centre, Amersham, Buckinghamshire.

\section{RESUL'TS}

\section{Incorporation of radioactivity from labelled glucose}

\section{(a) Unstarved cells}

Assay of the radioactivity in the various fractions obtained from the cell extracts showed that glucose was metabolized very rapidly (Table 1). The fractions contained radioactive substances from the medium as well as from the extracted cells, and the very high activity in the non-ionic fraction in the early stages was due largely to unmetabolized glucose.

Two substances appeared in the chromatograms of the cationic fraction, one of which was glutamic acid, the other not being identified. Substantially the same pattern of radioactivity was demonstrated by the cationic fraction of each of the cell extracts from $15 \mathrm{sec}$. to $6 \mathrm{~min}$. 
In the anionic fractions only succinate was identified, though a number of other active substances were present. Succinate appeared labelled in the $15 \mathrm{sec}$. extract, and remained visible in the $45 \mathrm{sec}$, and very faintly in the

\section{Table 1. Distribution of radioactivity in unstarved cells fed uniformly-labelled glucose}

A number of samples of cell suspension, each containing $60 \mathrm{mg}$. dry wt. of cells, were supplied with $12.5 \mu \mathrm{c}$. $\left(160 \mu \mathrm{g}\right.$.) of $\left({ }^{14} \mathrm{C}\right)$ glucose. At intervals samples were mixed with boiling ethanol to kill and extract the cells. The extracts were fractionated into anionic, cationic and non-ionic fractions by ion-exchange resins. The activity of each fraction was determined, together with the radioactivity incorporated into the insoluble cell material. The values given below are the total for each sample of suspension. As the cells were not separated from the medium before extraction, the high activity of the non-ionic fraction is largely due to unutilized glucose.

$\begin{array}{ccccc}\begin{array}{c}\text { Incubation } \\ \text { period } \\ \text { (sec.) }\end{array} & \begin{array}{c}\text { Anionic } \\ \text { fraction } \\ \text { (counts/min.) }\end{array} & \begin{array}{c}\text { Cationic } \\ \text { fraction } \\ \text { (counts/min.) }\end{array} & \begin{array}{c}\text { Non-ionic } \\ \text { fraction } \\ \text { (counts/min.) }\end{array} & \begin{array}{c}\text { Insoluble } \\ \text { material } \\ \text { (counts/min.) }\end{array} \\ \mathbf{1 5} & \mathbf{2 2 5 , 0 0 0} & \mathbf{1 9 1 , 0 0 0} & \mathbf{8 , 4 0 0 , 0 0 0} & \mathbf{3 0 , 0 0 0} \\ \mathbf{4 5} & \mathbf{1 8 5 , 0 0 0} & \mathbf{2 8 6 , 0 0 0} & \mathbf{7 , 7 6 0 , 0 0 0} & \mathbf{3 1 , 0 0 0} \\ 120 & \mathbf{6 7 2 , 0 0 0} & \mathbf{2 3 0 , 0 0 0} & \mathbf{6 , 7 2 7 , 0 0 0} & \mathbf{1 0 6 , 0 0 0} \\ \mathbf{3 6 0} & \mathbf{2 , 2 6 8 , 0 0 0} & \mathbf{2 9 7 , 0 0 0} & \mathbf{2 , 6 4 4 , 0 0 0} & \mathbf{6 9 9 , 0 0 0}\end{array}$

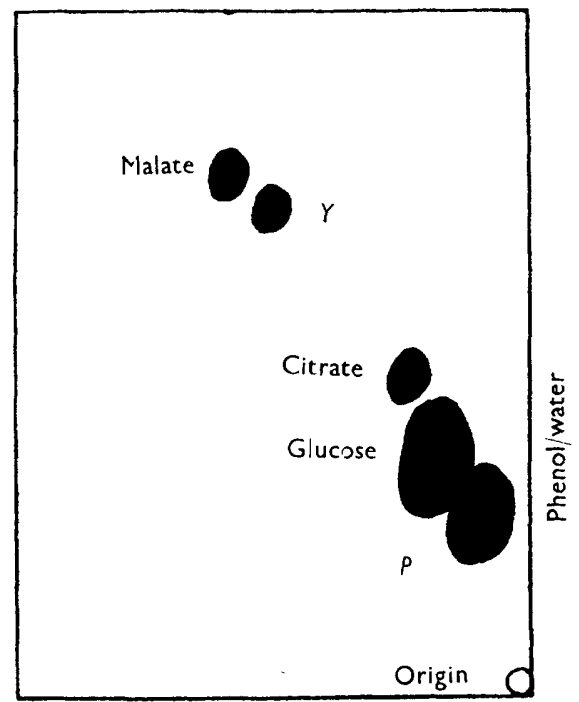

Butanol/butyric acid/water

Fig. 1. Diagram of chromatogram of non-ionic fraction of cell extract showing the location of the radioactive areas mentioned in the text. Cells supplied with radioactive glucose extracted with hot ethanol. Extract separated into cationic, anionic, and non-ionic fractions with ion-exchange resins.

2 min. extracts. There was a considerable degree of change in this fraction, substances present in the 15 sec. extracts decreasing greatly in activity or being entirely absent after 6 min., and different active substances taking their places. 
The 'non-ionic' fraction showed a rapidly decreasing radioactivity during the course of the experiment corresponding to the utilization of labelled glucose. After 6 min. almost the entire supply of glucose had been metabolized. Malate and citrate both incorporated activity from glucose. In 15 sec. almost every compound in this fraction which was eventually to appear containing labelled carbon could already be seen in the radioautograms. As the experiment progressed these compounds gradually disappeared as the supply of glucose was utilized. An unidentified substance $Y$ appeared only in the 15 sec. extract. Malate and citrate remained labelled after $6 \mathrm{~min}$. A diagram indicating the relative positions of the various substances in this fraction is shown in Fig. 1.

No activity could be found on the chromatograms in the areas known from preliminary experiments to be the locations of $\alpha$-ketoglutarate, fumarate, pyruvate, malonate, tartarate, oxalate, glyoxylate, oxalacetate, isocitrate, cis-aconitate, itaconate, lactate, dihydroxyacetone, glucose-1-phosphate, glucose-6-phosphate, fructose-1:6-diphosphate, phosphoglycerate, 6-phosphogluconate, gluconate, 2-ketogluconate and 5-ketogluconate. While no attempt was made to identify these substances chemically owing to the small amounts of cell extracted, Millbank (1954) has reported the presence of low concentrations of $\alpha$-ketoglutarate and pyruvate in cell extracts of this fungus, and fumarate has also been detected.

\section{(b) Starved cells}

The distribution of radioactivity in the various fractions of the extracts of starved cells is given in Table 2. Glucose again was metabolized rapidly, and a comparison with the values given in Table 1 shows that the activity present in the extract after $15 \mathrm{sec}$. was approximately similar to that present in the extract of unstarved cells after the same incubation period. However, activity was incorporated into the ethanol-insoluble material more slowly in cells which had been starved in buffer.

Table 2. Distribution of radioactivity in starved cells fed uniformly-labelled glucose

The details are the same as those for Table 1, except that the cells were starved for $24 \mathrm{hr}$. in $\mathbf{0 . 0 6 7} \mathrm{M}$-phosphate buffer, $\mathrm{pH} 6 \cdot 8$, for $24 \mathrm{hr}$. after growth.

\begin{tabular}{|c|c|c|c|c|}
\hline $\begin{array}{l}\text { Incubation } \\
\text { period } \\
\text { (sec.) }\end{array}$ & $\begin{array}{c}\text { Anionic } \\
\text { fraction } \\
\text { (counts/min.) }\end{array}$ & $\begin{array}{c}\text { Cationic } \\
\text { fraction } \\
\text { (counts/min.) }\end{array}$ & $\begin{array}{c}\text { Non-ionic } \\
\text { fraction } \\
\text { (counts/min.) }\end{array}$ & $\begin{array}{c}\text { Insoluble } \\
\text { material } \\
\text { (counts } / \mathrm{min} .)\end{array}$ \\
\hline 15 & 211,000 & 402,000 & $6,478,000$ & 28,000 \\
\hline 45 & 249,000 & 446,000 & $6,718,000$ & 54,000 \\
\hline 120 & 216,000 & 434,000 & $6,978,000$ & 71,000 \\
\hline 360 & 283,000 & 543,000 & $6,244,000$ & 304,000 \\
\hline 1200 & 432,000 & 962,000 & $4,530,000$ & 958,000 \\
\hline
\end{tabular}

Radioautograms of the cationic fraction showed two weakly labelled substances which did not correspond to any amino acid tested, and were not identified. 
The anionic fraction after 15 sec. contained two prominent substances, neither of which was present in the corresponding fraction from unstarved cells. One of these was identified as glucose-1-phosphate; the other was not identified. Other compounds appeared later in the experiment, among them succinate, first appearing after 2 min., and fructose-1:6-diphosphate, which appeared after $45 \mathrm{sec}$; these substances remained visible after $20 \mathrm{~min}$.

In the non-ionic fractions a pronounced glucose spot was visible throughout the incubation period and the radioactivity measured in this fraction remained correspondingly high after $20 \mathrm{~min}$. (Table 2). Citrate and malate were labelled from 15 sec. onwards. There were, however, considerable differences in this fraction between the starved and unstarved cells. The unidentified substance $Y$ which appeared after $15 \mathrm{sec}$. in unstarved cells did not appear at all in extracts of starved cells, nor did some other fainter spots. In the starved cells several other weak spots were visible. After $6 \mathrm{~min}$. a compound appeared in starved cells $(P)$ which after 20 min. was almost as intense as glucose (Fig. 1). This substance was not identified.

\title{
Incorporation of radioactivity from carboxyl-labelled acetate
}

The radioactivities present in the media of the cell suspensions I, II and III at the beginning and end of the incubation period are shown in Table $\mathbf{3}$, together with the activities incorporated into the cells and released in the respired carbon dioxide.

\section{Table 3. The utilization of acetate carboxyl carbon and release of carbon dioxide by three samples of cells}

\begin{abstract}
$50 \mathrm{ml}$. of each cell suspension was shaken in a $500 \mathrm{ml}$. Erlenmeyer flask in the presence of unlabelled glucose and carboxyl-labelled acetate. Measurements were made of the initial and final radioactivities in the media. In similar experiments in Warburg flasks the ${ }^{14} \mathrm{CO}_{2}$ evolved by aliquots of the cell suspensions was measured. There was no significant source of radioactivity in the medium other than acetate. The values given represent the total quantities used in each case and are expressed as counts $/ \mathrm{min}$. Cells of sample I were unstarved. Cells of sample II were starved overnight in phosphate buffer, and cells of sample III were starved overnight and then allowed to metabolize glucose for $3 \mathrm{hr}$.
\end{abstract}

$\begin{array}{lrrr} & \text { Sample I } & \text { Sample II } & \text { Sample III } \\ \text { Initial }\left({ }^{14} \mathrm{C}\right) \text { acetate in the medium } & \mathbf{2 6 , 1 0 8 , 0 0 0} & \mathbf{2 6 , 1 0 8 , 0 0 0} & \mathbf{2 6 , 1 0 8 , 0 0 0} \\ \text { Final }\left({ }^{14} \mathrm{C}\right) \text { acetate in the medium } & \mathbf{1 2 , 5 9 0 , 0 0 0} & \mathbf{2 0 , 2 3 5 , 0 0 0} & \mathbf{1 1 2 , 0 0 0} \\ \text { Thus }\left({ }^{14} \mathrm{C}\right) \text { acetate utilized } & 13,518,000 & \mathbf{5 , 8 7 3 , 0 0 0} & \mathbf{2 5 , 9 9 6 , 0 0 0} \\ { }^{14} \mathrm{CO}_{2} \text { released } & \mathbf{2 , 2 7 5 , 0 0 0} & \mathbf{2 , 3 4 7 , 0 0 0} & \mathbf{1 0 , 4 8 2 , 0 0 0} \\ \text { Thus }{ }^{14} \mathrm{C} \text { incorporated into the cells } & \mathbf{1 1 , 2 4 3 , 0 0 0} & \mathbf{3 , 5 2 6 , 0 0 0} & \mathbf{1 5 , 5 1 4 , 0 0 0}\end{array}$

The specific activities of the glutamic acid isolated from each cell sample and of the $\alpha$-carboxyl carbons are given in Table 4 . From these values it is possible to calculate the percentage of the oxalacetate used for citrate formation in the tricarboxylic acid cycle which is formed from recycled $\mathrm{C}_{4}$-dicarboxylic acids $(K)$ compared with the percentage of oxalacetate synthesized afresh from carbon dioxide and pyruvate $(\boldsymbol{P})$. This $\boldsymbol{P} / \boldsymbol{K}$ ratio is an indication of the extent of recycling taking place within the tricarboxylic acid cycle (Roberts, Cowie, 
Britten, Bolton \& Abelson, 1953). The results in Table 4 show that the degree of recirculation increased when the cells were starved and later resupplied with glucose.

\section{Table 4. Radioactivity of glutamic acid obtained from three samples of cells}

Glutamic acid was isolated from three samples of cells supplied with unlabelled glucose and carboxyl-labelled acetate. Cells of sample I were unstarved. Cells of sample II were starved for $24 \mathrm{hr}$. in phosphate buffer, and cells of sample III were starved and then allowed to metabolize glucose for $3 \mathrm{hr}$. Each glutamate sample was decarboxylated and the specific activities of the glutamic acids and their $\alpha$-carboxyl carbons are given as counts $/ \mathrm{min}$. $/ \mu$ mole. The $P / K$ value is derived from the percentage of the oxalacetate utilized in citrate synthesis which is formed from recycled $C_{4}$ dicarboxylic acid $(K)$ compared with the percentage synthesized de novo from pyruvate and carbon dioxide $(P)$.

Specific activity of glutamic acid Specific activity of $\alpha$-carboxyl carbon of glutamic acid

$$
P / K^{*}
$$

$\begin{array}{ccc}\text { Sample I } & \text { Sample II } & \text { Sample III } \\ 4,984 & \mathbf{9 , 0 2 6} & 15,799 \\ 1,138 & 2,531 & 4,902 \\ 41 / 59 & 22 / 78 & 10 / 90\end{array}$

* The $P / K$ value for growing cells was previously found from glutamic acid labelling to be $40 / 60$ (Moses, 1957).

\section{Respiration of labelled glucose}

By allowing similar suspensions of cells to oxidize $\left({ }^{14} \mathrm{C}\right)$ glucose and ${ }^{14}\left(\mathrm{C}_{1}\right)$ glucose and measuring the uptake of the marked glucose and the radioactivity present in the respired carbon dioxide, it is possible, assuming that all the ${ }^{14} \mathrm{CO}_{2}$ derived from $\left({ }^{14} \mathrm{C}_{1}\right)$ glucose is released before the glucose molecule is split into smaller units, to estimate the percentage of glucose metabolized by a primary attack at the $\mathrm{C}_{1}$ position (Heath \& Koffler, 1956). The ${ }^{14} \mathrm{CO}_{2}$ produced from $\left({ }^{14} \mathrm{C}_{1}\right)$ glucose is a measure of the extent of oxidation of the $\mathrm{C}_{1}$ atom. Knowing this, together with the total activity of the ${ }^{14} \mathrm{CO}_{2}$ from $\left({ }^{14} \mathrm{C}\right)$ glucose and the amount of $\left.{ }^{14} \mathrm{C}\right)$ glucose utilized, the proportion of ${ }^{14} \mathrm{CO}_{2}$ produced from the other carbon atoms can be calculated. As a symmetrical breakdown of glucose would produce ${ }^{14} \mathrm{CO}_{2}$ from all carbon atoms, the preferential quantity derived from the $\mathrm{C}_{1}$ position can be used to estimate the extent of primary attack at this position.

This technique has been carried out with cells in the four physiological states described above, and the results are presented in Table 5. The findings showed that while growing cells attacked about $11 \%$ of the glucose primarily at the $\mathrm{C}_{1}$ position, in resting cells this value had risen to nearly $20 \%$; after starvation the utilization of this route was less than $1 \%$ immediately glucose was supplied, but 3-4 hr. later it had risen to $5 \%$ (Table 5).

Under anaerobic conditions resting cells (sample $\mathrm{I}$ ) produced about six times more ${ }^{14} \mathrm{CO}_{2}$ from $\left({ }^{14} \mathrm{C}\right)$ glucose than from $\left({ }^{14} \mathrm{C}_{1}\right)$ glucose of the same specific activity. In the Embden-Meyerhof glycolysis scheme no carbon dioxide would be produced from the $\mathrm{C}_{1}$ of glucose; the fungus thus uses some other pathway to some extent in glucose fermentation. DeMoss (1953) has recorded an instance of carbon dioxide being produced from the first carbon atom of glucose during fermentation by Pseudomonas lindneri. 


\section{Table 5. Utilization of $\left({ }^{14} \mathrm{C}\right)$ glucose and $\left({ }^{14} \mathrm{C}_{1}\right)$ glucose, and release of respired}

$$
{ }^{14} \mathrm{CO}_{2} \text {, by four samples of cells }
$$

Each Warburg flask contained $2 \mathrm{ml}$. of cell suspension in $0.067 \mathrm{M}$-phosphate buffer, pH 6.8 (except cells of sample IV, which were suspended in growth medium), and $0.2 \mathrm{ml}$. of $\mathrm{N}-\mathrm{KOH}$ in the centre well. $\left({ }^{14} \mathrm{C}\right)$ or $\left({ }^{14} \mathrm{C}_{1}\right)$ glucose was added from the side arm to give a concentration of $0.002 \mathrm{M}$. The gas phase was air for samples I-III, and $\mathrm{O}_{2}$ for sample IV. After being shaken for $1 \mathrm{hr}$. at $25^{\circ}$ analyses were made of the medium and $\mathrm{KOH}$ for the activities of the residual glucose and respired carbon dioxide, respectively. The initial activities of both the labelled substrates were adjusted to the same value. Cells of sample I were unstarved, cells of sample II were starved for $\mathbf{2 4} \mathrm{hr}$. in phosphate buffer, and cells of sample III were starved and then allowed to metabolize glucose for $3 \mathrm{hr}$. Cells of sample IV were growing. Values for the radioactivities are totals and are expressed as counts/min./flask. The method of calculation is that of Heath \& Koffler (1956).

\begin{tabular}{|c|c|c|c|c|}
\hline & Sample I & Sample II & Sample III & Sample IV \\
\hline $\begin{array}{l}\text { Initial }\left({ }^{14} \mathrm{C}\right) \text { glucose or }\left({ }^{14} \mathrm{C}_{1}\right)- \\
\text { glucose in the medium }\end{array}$ & $1,676,000$ & $1,676,000$ & $1,676,000$ & $1,676,000$ \\
\hline $\begin{array}{l}\text { Final }\left({ }^{14} \mathrm{C}\right) \text { glucose or }\left({ }^{14} \mathrm{C}_{1}\right) \text { glucose } \\
\text { in the medium }\end{array}$ & 107,000 & 659,000 & 242,000 & $1,508,000$ \\
\hline $\begin{array}{l}\text { Thus }\left({ }^{14} \mathrm{C}\right) \text { glucose or }\left({ }^{14} \mathrm{C}_{1}\right) \text { glucose } \\
\text { utilized }\end{array}$ & $1,569,000$ & $1,017,000$ & $1,434,000$ & 168,000 \\
\hline $\begin{array}{l}{ }^{14} \mathrm{CO}_{2} \text { produced from }\left({ }^{14} \mathrm{C}_{1}\right)- \\
\text { glucose }\end{array}$ & 679,000 & 90,000 & 275,000 & 83,000 \\
\hline${ }^{14} \mathrm{CO}_{2}$ produced from $\left({ }^{14} \mathrm{C}\right)$ glucose & 427,000 & 84,000 & 219,000 & 68,000 \\
\hline $\begin{array}{l}\text { Percentage of the total }\left({ }^{14} C_{1}\right)- \\
\text { glucose activity utilized ap- } \\
\text { pearing in } \mathrm{CO}_{2}\end{array}$ & 43 & $8 \cdot 8$ & 19 & 49 \\
\hline $\begin{array}{l}\text { Activity in each } \mathrm{C} \text { atom of }\left({ }^{14} \mathrm{C}\right) \text { - } \\
\text { glucose utilized }\end{array}$ & 262,000 & 170,000 & 239,000 & 28,000 \\
\hline $\begin{array}{l}\text { Activity in }{ }^{14} \mathrm{CO}_{2} \text { from }\left({ }^{14} \mathrm{C}\right)- \\
\text { glucose which is derived from } \\
\text { oxidation of } \mathrm{C}_{1}\end{array}$ & 112,000 & 15,000 & 46,000 & 13,000 \\
\hline $\begin{array}{l}\text { Thus, activity in }{ }^{14} \mathrm{CO}_{2} \text { from } \\
\left({ }^{14} \mathrm{C}\right) \text { glucose derived from } \mathrm{C}_{2-6}\end{array}$ & 315,000 & 69,000 & 173,000 & 54,000 \\
\hline $\begin{array}{l}\text { Total activity in } \mathrm{C}_{2-6} \text { of }\left({ }^{14} \mathrm{C}\right) \text { - } \\
\text { glucose utilized }\end{array}$ & $1,308,000$ & 848,000 & $1,195,000$ & 140,000 \\
\hline $\begin{array}{l}\text { Percentage of activity in } \mathrm{C}_{2-6} \\
\text { utilized appearing in } \mathrm{CO}_{2}\end{array}$ & 24 & $8 \cdot 2$ & 14 & 38 \\
\hline $\begin{array}{l}\text { Minimum proportion of glucose } \\
\text { metabolized by a primary } \\
\text { attack at } \mathrm{C}_{1}(\%)\end{array}$ & 19 & $0 \cdot 6$ & $\mathbf{5}$ & 11 \\
\hline
\end{tabular}

\section{DISCUSSION}

Cells of this organism possess all the enzymes necessary to carry out the reactions of the tricarboxylic acid cycle (Moses, 1955c), and it has recently been shown that the cycle plays an important part in the respiration of growing cells (Moses, 1957). The present finding that radiocarbon from glucose is incorporated into succinate, malate, citrate, and glutamate in unstarved cells is in accord with the earlier results.

As many of the substances deriving radioactivity from glucose were not identified it was not possible to come to any conclusions as to the pathway of glucose metabolism save that the tricarboxylic acid cycle appeared to be involved and that, in starved cells at any rate, glucose carbon was metabolized at least to some extent via glucose-1-phosphate and fructose-1:6-diphosphate. 
More interesting are the differences which were found between the starved and the unstarved cells. It was previously suggested (Moses, 1955 a) that permeability considerations played some small part in the manifestation of the lag period of glucose metabolism when this substance was supplied to starved cells. Although the present work has shown that the rate of utilization of glucose carbon was slower in starved than in unstarved cells, the first appearance of radioactivity from glucose in a number of other substances including malate and citrate was nevertheless of the same order of rapidity in both types of cells.

Starvation resulted in a considerable change in the pattern of incorporation of glucose carbon. A number of substances, including glutamate, which became radioactive in unstarved cells possessed no detectable activity in starved cells. On the other hand, in starved cells many areas of activity appeared on the chromatograms which did not correspond with any in unstarved cells : notable among these were glucose-1-phosphate and fructose-1:6diphosphate. It is evident that starvation resulted in a considerable metabolic rearrangement and that the pathways involved in glucose utilization were different before and after starvation.

These conclusions are further borne out by kinetic studies using labelled glucose and acetate with cells in different physiological conditions. Of the

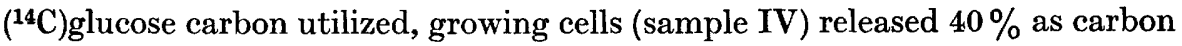
dioxide, resting cells (sample I) released $27 \%$, starved cells initially released $8 \%$ (sample II) which rose later to $15 \%$ (sample III) (Table 5). The minimum percentage of glucose attacked at the $\mathrm{C}_{1}$ position increased when the cells were removed from the growth medium and maintained in a resting condition, decreased after starvation and tended to return towards the resting value when the cells were supplied with glucose for some hours after starvation.

The degree of recycling in the tricarboxylic acid cycle is a measure of the extent to which the cycle is used as a mechanism for synthesis (e.g. of aspartic and glutamic acids) or as a respiratory pathway (Roberts et al. 1953). The synthetic significance of the cycle diminished after starvation and the cycle continued to be used predominantly as a respiratory mechanism for several hours after the cells were again allowed to respire glucose.

Labelled glucose and fructose phosphate are derived from radioactive glucose in starved but not in unstarved cells, and while in starved cells the proportion of glucose attacked at the first carbon position is nearly zero, in unstarved resting cells the proportion is nearly $20 \%$.

The radiochemicals and assay equipment were purchased with grants awarded by the Royal Society and the Central Research Fund of the University of London, respectively. Our thanks are due to the Trustees of the Lord Beaverbrook Scholarship Fund for a personal scholarship to one of us (G.W.B.). 


\section{REFERENCES}

Aronoff, S. \& Vernon, L. (1950). Metabolism of soybean leaves. I. 'The sequence of formation of soluble carbohydrates during photosynthesis. Arch. Biochem. 28, 424 .

Bandurski, R. S. \& Axelrod, B. (1951). The chromatographic identification of some biologically important phosphate esters. J. biol. Chem. 193, 405.

Claridge, C. A. \& Werkman, C. H. (1954). Intermediates of the aerobic dissimilation of 2-ketogluconate by Pseudomonas aeruginosa. Arch. Biochem. Biophys. 51,395 .

DeMoss, R. D. (1953). Routes of ethanol formation in bacteria. J. cell. comp. Physiol. 41, Suppl. 1, 207.

Hanes, C. S. \& Isherwood, F. A. (1949). Separation of the phosphoric esters on the filter paper chromatogram. Nature, Lond. 164, 1107.

Heath, E. C. \& Kofflfi, H. (1956). Biochemistry of filamentous fungi. II. The quantitative significance of an 'oxidative pathway'. J. Bact. 71, 174.

Milıbank, J. W. (1954). A study of intermediary metabolism in two micro-organisms, with particular reference to the keto-acids. Ph.D. Thesis, University of London.

Moses, V. (1954). The effect of ammonia on the oxidation of glucose by Zygorrhynchus moelleri. Biochem. J. 57, 547.

Moses, V. $(1955 a)$. Glucose respiration in Zygorrhynchus moelleri; the entry of glucose into the cells. J. exp. Bot. 6, 222.

Moses, V. $(1955 b)$. The disappearance of intermediates involved in glucose oxidation during the starvation of the fungus Zygorrhynchus moelleri. Ann. Bot., Lond., N.S. 19, 211.

Moses, V. $(\mathbf{1 9 5 5} c)$. 'Tricarboxylic acid cycle reactions in the fungus Zygorrhynchus moelleri. J. gen. Microbiol. 13, 235.

Moses, V. (1957). The metabolic significance of the citric acid cycle in the growth of the fungus Zygorrhynchus moelleri, J. gen. Microbiol. 16, 534.

Norris, F. C. \& CAmpberl, J. J. R. (1949). The intermediate metabolism of Pseudomonas aeruginosa. III. The application of paper chromatography to the identification of gluconic and 2-ketogluconic acids, intermediates in glucose oxidation. Canad. J. Res. $27 \mathrm{C}, 253$.

Roberts, R. B., Cowie, D. B., Britten, R., Bolton, E. \& Abelson, P. H. (1953). The role of the tricarboxylic acid cycle in amino acid synthesis in Escherichia coli. Proc. nat. Acad. Sci., Wash. 39, 1013.

'Trevelyan, W. E., Procter, D. P. \& Harrison, J. S. (1950). Detection of sugar on paper chromatograms. Nature, Lond. 166, 444.

(Received 19 September 1956) 